\title{
Genetic studies in upland cotton (Gossypium hirsutum L.) for earliness and yield contributing traits
}

Sabir Hussain Kaleri ${ }^{1}$, Arshad Ali Kaleri ${ }^{*}$, Abdul Wahid Baloch ${ }^{1}$, Shah Nawaz Mari ${ }^{1}$, Sajid Hussain Kaleri ${ }^{2}$, Naila Gandahi ${ }^{1}$, Wajid Ali Jatoi ${ }^{1}$, Tanweer Fatah Abro $^{1}$ and Mohsin Khan ${ }^{3}$

1. Department of Plant breeding \& Genetics, S.A.U Tandojam-Pakistan

2. Department of Soil Science, S.A.U Tandojam-Pakistan

3. Department of Biotechnology, S.A.U Tandojam-Pakistan

*Corresponding author's email: Ali.breeder110@gmail.com

Citation

Sabir Hussain Kaleri, Arshad Ali Kaleri, Abdul Wahid Baloch, Shah Nawaz Mari, Sajid Hussain Kaleri, Naila Gandahi, Wajid Ali Jatoi, Tanweer Fatah Abro and Mohsin Khan. Genetic studies in upland cotton (Gossypium hirsutum L.) for earliness and yield contributing traits. Pure and Applied Biology. Vol. 6, Issue 1, pp153-158. http://dx.doi.org/10.19045/bspab.2017.60008

Received: 10/11/2016 Revised: 09/01/2017

Accepted: 14/01/2017

Online First: 18/01/2017

\section{Abstract}

The current experiment was conducted to evaluate the genetics for earliness and yield traits in upland cotton (Gossypium hirsutum L.) during Kharif season 2013 at Cotton Section, Agriculture Research Institute, Tandojam. The experiment was laid out in a randomized complete block design with three replications. The experiment consisted of fifteen genotypes in which ten $\mathrm{F}_{1}$ were developed from five parents crossed in a $5 \times 5$ diallel matting design for days to $1^{\text {st }}$ flower, bolls formed at 90 days after planting, bolls opened at 90 days after planting, plant height $(\mathrm{cm})$, sympodial branches plant ${ }^{-1}$, bolls plant ${ }^{-1}$, boll weight $(\mathrm{g})$ and seed cotton yield plant ${ }^{-1}(\mathrm{~g})$. The genotypes were significantly different $(\mathrm{P} \leq 0.05)$ for days to $1^{\text {st }}$ flower, bolls formed at 90 days after planting, bolls opened at 90 days after planting, plant height, sympodial branches plant ${ }^{-1}$, bolls plant ${ }^{-1}$ and seed cotton yield plant ${ }^{-1}$. Among the genotypes, Sindh-1, CRIS-134 and Shahbaz were best general combiners for days to $1^{\text {st }}$ flower, bolls formed at 90 days after planting, bolls opened at 90 days after planting, plant height, sympodial branches plant ${ }^{-1}$, bolls plant $^{-1}$, boll weight and seed cotton yield plant ${ }^{-1}$. The $F_{1}$ hybrids Sadori x Sindh-1, Shabaz $x$ Haridost, Sadori x CIM-496 were best specific combiners for all the characters studied. The $\mathrm{F}_{1}$ hybrids Shahbaz x Sindh-1, Sadori x Sindh-1, Sadori x Haridost and Sadori x CIM-496 gave higher heterotic effects for all the studied traits.

Keywords: Earliness; Diallel; Seed cotton yield; Upland cotton; Earliness traits

\section{Introduction}

Cotton occupies a unique position in Pakistan's agrarian economy. Efforts on various aspects of the crop have been under way to increase overall production of the country. Cotton is principal component of Pakistan's economy owing to its $69 \%$ share in foreign exchange earning, $7.5 \%$ value addition in agriculture and $1.6 \%$ in GDP. It contributes about $78 \%$ in domestic oil 
production. It is a powerful source for our economic growth because it plays an efficient role in enhancing the national economy by earning a huge share of the total foreign exchange. It enhances textile exports of cotton with made items like raw cotton, cotton yarn, bed wear, towels, cotton cloths and synthetic fabrics knit wear and readymade garments to foreign countries and embrace more than $\$ 7.3$ billion to the national economy which is around two thirds of the country's export earnings [1]. Cotton breeders hence are very keen in determining the genetic potential of their inbred parents in hybrid combinations for two reasons. First is that, inbred parents be identified which form good individuals in specific combinations, which is commonly referred as specific combining ability (SCA) of the inbred parents. Second purpose is, to locate those inbred lines which perform very well when crossed with a series of other inbred parents referred as general combining ability (GCA) of the parents. Thus, former types of inbreds are useful for hybrid cotton development, whereas later types are desirable for hybridization and selection from segregation populations. The primary objectives of this study were to determine the genetic potential in upland cotton cultivars, such information can usefully be subjugated in articulating efficient selection program for synthesis and development of new cotton genotypes with improved traits for earliness and seed cotton yield.

\section{Materials and methods}

The study was conducted during Kharif season of 2013 at Cotton Section, Agriculture Research Institute, Tandojam in randomized complete block design with three replications to evaluate genetics for earliness in upland cotton (Gossypium hirsutum L.). The experiment was consisted of fifteen genotypes in which five were parents $\left(\mathrm{P}_{1}=\right.$ Shahbaz, $\mathrm{P}_{2}=\mathrm{CIM}-496, \mathrm{P}_{3}=$ Sindh-1, $\mathrm{P}_{4}=$ Sadori, $\mathrm{P}_{5}=$ Hari-Dost) and the rest were $\mathrm{F}_{1}$ hybrids $\left(\mathrm{C}_{1}=\right.$ ShahbazxCIM496, $\mathrm{C}_{2}=$ Shahbaz $x$ Sindh $1, \mathrm{C}_{3}=$ Shahbaz $\mathrm{x}$ Sadori, $\mathrm{C}_{4}=$ Shahbaz $\mathrm{x}$ Haridost, $\mathrm{C}_{5}=\mathrm{CIM}-$ $496 \times$ Sindh-1, $\mathrm{C}_{6}=\mathrm{CIM}-496$ x Sadori, $\mathrm{C}_{7}=\mathrm{CIM}-496 \quad \mathrm{x}$ Haridost, $\mathrm{C}_{8}=$ Sindh-1 $\mathrm{x}$ Sadori, $\mathrm{C}_{9}=$ Sindh $-1 \times$ Haridost, $\mathrm{C}_{10}=$ Sadori $x$ Haridost) were developed from a 5x 5 diallel matting design. Cotton seeds were sown by dibbling method, plant to plant and row to row distance was kept 30 and $75 \mathrm{~cm}$, respectively.

\section{Results and discussion}

The study was conducted during Kharif season of 2013 at Cotton Section, Agriculture Research Institute, Tandojam in randomized complete block design with three replications. In context to evaluate genetics for earliness and yield related traits in upland cotton (Gossypium hirsutum L.).The experiment consisted of fifteen genotypes in which five were parents and the rest were $F_{1}$ hybrids in a $5 \times 5$ diallel matting design for days to $1^{\text {st }}$ flower, bolls formed at 90 days after planting, bolls opened at 90 days after planting, plant height $(\mathrm{cm})$, sympodial branches plant $^{1}$, bolls plant ${ }^{1}$, boll weight (g) and seed cotton yield plant ${ }^{1}(\mathrm{~g})$. The obtained mean squares from analysis of variances exhibited highly significant differences $(\mathrm{P} \leq 0.05)$ for all the studied traits among the assessed genotypes except that of boll weight, which was nonsignificant (Table 1). This reveals that examined genetic materials have value to be used in more breeding programs for the improvement of upland cotton in respect to fiber and yield. Kaleri et al.[2] also reported that a set $\mathrm{Bt}$ and non-Bt cotton genotypes differed highly significantly at $\mathrm{P} \leq 0.01$ of probability level for plant height, $1^{\text {st }}$ sympodial node number, $1^{\text {st }}$ effective boll node number, sympodial branches plant $^{-1}$, bolls plant $^{-1}$, boll weight, seed index, micronaire value, staple length, ginning outturn percentage and seed cotton yield plant $^{-1}$. 
Table 1. Mean squares from analysis of variance for various quantitative traits in upland cotton

\begin{tabular}{|c|c|c|c|}
\hline Source of variation & $\begin{array}{c}\text { Replication } \\
(\mathbf{D . F . = 2})\end{array}$ & $\begin{array}{c}\text { Genotypes } \\
\text { (D.F.=16) }\end{array}$ & $\begin{array}{c}\text { Error } \\
\text { (D.F.=32) }\end{array}$ \\
\hline Days to $1^{\text {st }}$ flower & 3.45 & $210.13^{* *}$ & 10.89 \\
\hline Bolls formed at 90 DAP & 8.97 & $345.14^{* *}$ & 8.31 \\
\hline Bolls opened at 90 DAP $^{*}$ DAP & 15.14 & $210.00^{* *}$ & 2.30 \\
\hline Plant height & 30.35 & $398.89^{* *}$ & 15.31 \\
\hline Sympodial branches plant $^{-1}$ & 4.38 & $24.30^{*}$ & 1.89 \\
\hline Bolls plant $^{-1}$ & 10.25 & $123.89^{* *}$ & 15.60 \\
\hline Boll weight $^{\text {Seedcotton yield plant }}{ }^{-1}$ & 3.95 & $15.60^{\text {NS }}$ & 8.85 \\
\hline
\end{tabular}

$*$,** indicates significant level at 5 and $1 \%$ of probability level; NS= Non-significant

With regard to GCA effects, among the five parents, Shahbaz recorded maximum (2.89) GCA effects for days to $1^{\text {st }}$ flower, followed by CIM-496 (1.60), while Sindh-1 recorded maximum (1.25) GCA effects for bolls formed at 90 DAP and also showed maximum (3.00) GCA for bolls opened at 90 DAP. Whereas, Haridost gave maximum (1.95) GCA effects for plant height, followed by CIM-496 (1.25) for same trait; parent Sadori recorded highest (1.90) GCA effects for sympodial branches plant ${ }^{-1}$ and also expressed the highest GCA effects (2.10) for seed cotton yield plant ${ }^{-1}$. Sindh-1 recorded maximum GCA (1.30) effects for bolls plant ${ }^{-1}$ and CIM-496 gave the highest GCA (0.45) for boll weight (Table 2). Similarly, Abro et al. [3] showed that the variety Sadori proved to be best general combiner for plant height, number of bolls plant $^{-1}$ and seed cotton yield.

Table 2. General combining ability (GCA) of the parents for earliness and yield traits in upland cotton

\begin{tabular}{|c|c|c|c|c|c|c|}
\hline Genotypes & Shahbaz & CIM-496 & Sindh-1 & Sadori & Haridost & S.E.(gi) \\
\hline Days to 1 $^{\text {st }}$ flower & 2.89 & 1.60 & 0.89 & -2.60 & -1.78 & 0.10 \\
\hline Bolls formed at 90 DAP & -0.45 & -0.90 & 1.25 & 0.35 & -0.25 & 0.05 \\
\hline Bolls opened at 90 DAP & 1.15 & 2.80 & 3.00 & -4.80 & -2.15 & 0.78 \\
\hline Plant height & -2.05 & 1.25 & -2.25 & 0.90 & 1.95 & 0.65 \\
\hline Sympodia plant $^{-1}$ & -1.90 & 0.85 & 0.85 & 1.90 & -1.10 & 0.45 \\
\hline Bolls plant $^{-1}$ & -1.70 & 0.65 & 1.30 & 0.35 & -1.60 & 0.32 \\
\hline Boll weight $^{\text {Seedcotton yield plant }}{ }^{-1}$ & 0.02 & 0.08 & 0.45 & 0.10 & -0.65 & 0.005 \\
\hline Seen $^{-1.90}$ & -2.80 & 0.80 & 2.10 & -1.80 & 1.10 \\
\hline
\end{tabular}

Regarding SCA effects, Shahbaz x Sindh-1 gave the higher (3.45) SCA effects for days to $1^{\text {st }}$ flower and bolls formed at 90 DAP, while Sindh-1 x Sadori recorded high (3.45) SCA effects for boll opening at 90 DAP, followed by Shahbaz x Haridost (2.67). However, Shahbaz x Sadori produced high
(5.60) SCA effects for plant height, followed by CIM-496 x Sindh-1 (3.90) SCA effects for same trait and Sindh-1 x Sadori gave the higher SCA effects $\quad(3.89,8.90,1.00$ and15.98) for sympodial branches plant ${ }^{-1}$, bolls plant ${ }^{-1}$, boll weight and seed cotton yield plant $^{-1}$, respectively among the ten 
crosses (Table 3). Similar to our findings, Baloch et al. [4] reported SCA estimates for hybrids FH-901 x CIM-506, which expressed maximum effects for ginning outturn percentage (4.00) and micronaire value (0.33); NB-999 x CIM-497 for earliness (5.29) and staple length (1.69) and FH-901 x CIM-497 (16.17) for plant height.

Table 3. Specific combining ability (SCA) effects of the $F_{1}$ hybrid for earliness and yield traits in upland cotton

\begin{tabular}{|c|c|c|c|c|c|c|c|c|}
\hline Genotypes & $\begin{array}{c}\text { Days } \\
\text { to 1 } \\
\text { flower }\end{array}$ & $\begin{array}{c}\text { Bolls } \\
\text { formed } \\
\text { fot 90 } \\
\text { DAP }^{+}\end{array}$ & $\begin{array}{c}\text { Bolls } \\
\text { opened } \\
\text { at 90 } \\
\text { DAP }\end{array}$ & $\begin{array}{c}\text { Plant } \\
\text { height }\end{array}$ & $\begin{array}{c}\text { Sympodial } \\
\text { branches }_{\text {plant }} \mathbf{1}^{-1}\end{array}$ & $\begin{array}{c}\text { Bolls } \\
\text { plant }^{-1}\end{array}$ & $\begin{array}{c}\text { Boll } \\
\text { weight }^{\text {Seed }}\end{array}$ & $\begin{array}{c}\text { cotton } \\
\text { yield } \\
\text { plant }^{-1}\end{array}$ \\
\hline Shahbaz x CIM-496 & 1.20 & 2.90 & -1.00 & 1.90 & 0.90 & 2.89 & -0.34 & 3.56 \\
\hline Shahbaz x Sindh-1 & 3.45 & 3.45 & -0.05 & 3.45 & 0.67 & 3.45 & -0.20 & 4.50 \\
\hline Shahbaz x Sadori & -2.68 & 1.67 & 1.05 & 5.60 & -1.20 & -4.65 & 0.25 & -2.87 \\
\hline Shahbaz x Haridost & -0.80 & 2.78 & 2.67 & 3.89 & 0.98 & -2.80 & 0.45 & -4.56 \\
\hline CIM-496 x Sindh-1 & 2.34 & -2.12 & 0.65 & 3.90 & 1.90 & -1.40 & 0.42 & -3.59 \\
\hline CIM-496 x Sodri & -3.09 & 0.89 & 0.85 & 2.86 & -2.76 & 2.40 & 0.45 & 4.89 \\
\hline CIM-496 x Haridost & 2.36 & 2.00 & 1.20 & -1.80 & -1.65 & 1.65 & -1.90 & 6.56 \\
\hline Sindh-1 x Sodri & -1.90 & 2.85 & 3.45 & -2.44 & 3.89 & 8.90 & 1.00 & 15.98 \\
\hline Sindh-1 x Haridost & 1.43 & 1.65 & -1.35 & 1.00 & -1.30 & 2.56 & 0.60 & -10.67 \\
\hline Sadori x Haridost & 1.90 & 1.05 & 1.90 & 1.68 & 0.80 & 3.45 & -0.67 & 3.56 \\
\hline S.E (si) & 1.89 & 0.68 & 0.86 & 1.45 & 0.80 & 1.77 & 0.35 & 2.38 \\
\hline
\end{tabular}

Taking heterotic effects which is mentioned in Table 4 and 5, Shahbaz $x$ Sindh-1 manifested maximum $(8.80 \%$ and $5.18 \%)$ of relative and better parent heterosis for days to $1^{\text {st }}$ flower; Shahbaz $x$ Haridost gave the maximum $(26.15 \%)$ relative heterosis and Shahbaz x CIM-496 gave higher (3.69\%) better parent heterosis for bolls formed at 90 DAP and Shahbaz x CIM-496 disclosed maximum (20.97\% and $18.74 \%$ ) relative and better parent heterosis for plant height. CIM$496 \times$ Haridost recorded highest (38.46 and $35.00 \%$ ) relative and mid parent heterosis, followed by Sindh-1 x Haridost (19.13\% and $6.59 \%)$ and Shahbaz x Sindh-1 (12.43\% and $11.69 \%$ ) relative and better parent heterosis for sympodial branches plant ${ }^{-1}$, respectively and Shahbaz x Haridost gave maximum $(41.61 \%$ and $40.48 \%)$ relative and better parent heterosis for bolls plant ${ }^{-1}$, Sindh-1 x Haridost gave the higher $(17.65 \%$ and $11.50 \%$ ) relative and better parent heterosis for boll weight and Shahbaz $\mathrm{x}$ Sadori regarded higher $(42.91 \%$ and $33.61 \%$ ) relative and better parent heterosis for seed cotton yield plant $^{-1}$.Similar results were obtained by $[1,5,6]$ for carrying out similar research segments to estimate hybrid vigour in cotton. 
Table 4. Heterotic effects for various traits in upland cotton genotypes

\begin{tabular}{|c|c|c|c|c|c|c|c|c|}
\hline \multirow{2}{*}{ Genotypes } & \multicolumn{2}{|c|}{$\begin{array}{c}\text { Boll formed at } \\
\text { 90 days }\end{array}$} & \multicolumn{2}{c|}{$\begin{array}{c}\text { Boll opened at } \\
\text { 90 days }\end{array}$} & \multicolumn{2}{c|}{ Plant height } & \multicolumn{2}{c|}{$\begin{array}{c}\text { Sympodial } \\
\text { branches plant }\end{array}$} \\
\cline { 2 - 9 } & H & HB & H & HB & H & HB & H & HB \\
\hline Shahbaz x CIM-496 & 10.26 & 3.69 & -10.01 & -14.29 & 20.97 & 18.74 & 19.41 & 3.90 \\
\hline Shahbaz x Sindh-1 & 0.01 & -11.28 & -14.30 & -26.43 & 20.77 & 14.14 & 12.43 & 11.69 \\
\hline Shahbaz x Sadori & 12.20 & -0.82 & 30.43 & 18.39 & 4.35 & -4.55 & -13.37 & -11.69 \\
\hline Shahbaz x Haridost & 26.15 & -2.09 & 23.90 & 19.96 & -0.69 & -14.45 & 16.79 & 3.90 \\
\hline CIM-496 x Sindh-1 & -15.86 & -20.95 & -54.20 & -69.34 & -0.68 & -13.07 & 6.79 & -6.55 \\
\hline CIM-496 x Sodri & -4.28 & -10.42 & -47.40 & -40.50 & 7.73 & 3.66 & 13.86 & -2.51 \\
\hline CIM-496 x Haridost & 16.04 & -13.76 & -17.80 & -28.50 & 6.23 & -1.14 & 38.46 & 35.00 \\
\hline Sindh-1 x Sodri & -6.02 & -5.64 & -19.65 & -20.39 & -16.40 & -21.78 & 11.54 & 8.74 \\
\hline Sindh-1 x Haridost & 17.53 & -16.11 & -64.98 & -75.01 & -29.31 & -29.74 & 19.13 & 6.59 \\
\hline Sadori x Haridost & 19.08 & -15.21 & -58.44 & -70.17 & -25.74 & -25.74 & 11.42 & -2.51 \\
\hline
\end{tabular}

$\mathrm{H}=$ Mid-parent heterosis; $\mathrm{HB}=$ Better parent heterosis

Table 5. Heterotic effects for various traits in upland cotton genotypes

\begin{tabular}{|c|c|c|c|c|c|c|}
\hline \multirow{2}{*}{ Genotypes } & \multicolumn{2}{|c|}{ Bolls plant $^{\mathbf{1}}$} & \multicolumn{2}{c|}{ Boll weight } & \multicolumn{2}{c|}{$\begin{array}{c}\text { Seed cotton } \\
\text { yield plant }\end{array}$} \\
\cline { 2 - 6 } & H & HB & H & HB & H & HB \\
\hline Shahbaz x CIM-496 & -5.13 & -6.98 & -5.62 & -6.73 & 29.27 & 17.46 \\
\hline Shahbaz x Sindh-1 & 33.81 & 18.75 & -3.08 & -4.71 & 27.70 & 6.27 \\
\hline Shahbaz x Sadori & 27.51 & 6.49 & 1.00 & 0.00 & 42.91 & 33.61 \\
\hline Shahbaz x Haridost & 41.61 & 40.48 & 1.08 & -5.72 & 36.36 & 28.74 \\
\hline CIM-496 x Sindh-1 & 21.81 & 10.01 & -5.37 & -5.86 & -35.70 & -41.72 \\
\hline CIM-496 x Sodri & -19.75 & -31.90 & -12.31 & -14.19 & -19.30 & -30.96 \\
\hline CIM-496 x Haridost & 1.95 & 0.77 & -11.15 & -16.21 & 7.32 & -7.38 \\
\hline Sindh-1 x Sodri & -20.00 & -25.41 & 4.07 & 1.32 & 4.62 & -17.46 \\
\hline Sindh-1 x Haridost & 1.40 & -9.38 & 17.65 & 11.50 & 17.08 & -6.92 \\
\hline Sadori x Haridost & 2.88 & -13.52 & 16.79 & 7.92 & 35.27 & 33.86 \\
\hline
\end{tabular}

$\mathrm{H}=$ Mid-parent heterosis; $\mathrm{HB}=$ Better parent heterosis

\section{Conclusion}

All the genotypes were highly significant for most of the traits, however, boll weight was non-significant. Among the genotypes Sindh-1 and Shahbaz were best combiners for days to $1^{\text {st }}$ flower, bolls formed at 90 days after planting, bolls opened at 90 days after planting, plant height, sympodial branches plant ${ }^{1}$, bolls plant ${ }^{1}$, boll weight and seed cotton yield plant ${ }^{1}$. Among the $F_{1}$ hybrids the crosses Sadori $\mathrm{x}$ Sindh-1, Shabaz x Hari dost, Sadori x CIM-496 were best specific combiners for all the characters studied. The $\mathrm{F}_{1}$ hybrids Shahbaz x Sindh-1, Sadori $x$ Sindh-1, Sadori x Hari dost and Sadori x CIM-496 recorded higher heterotic effects for all the traits.

Authors' contributions

Conceived and designed the experiments: SN Mari, Performed the experiments: $\mathrm{SH}$ Kaleri \& AA Kaleri, Analyzed the data: AW Baloch \& AA Kaleri, Contributed reagents/ 
materials/ analysis tools: SH Kaleri \& AA Kaleri, Wrote the paper: AA Kaleri.

\section{References}

1. İlker E, Altınbaş $M$, Tosun $M$ \& Sakinoğlu ÇF (2008). Heterosis and genotypic variability for some yield and fiber properties in F2 generations of two cotton (Gossypium spp.) crosses. Ege Üniversitesi Ziraat Fakültesi Dergisi 45 (3): 153-163

2. Kaleri AA, Baloch AW, Baloch M, Wahocho NA, Abro TF, Jogi Q, Soomro AA, Marri A \& Bhutto LA (2016). Heritability and correlation analysis in $\mathrm{Bt}$ and non-Bt cotton (Gossypium hirsutum L.) genotypes. http://dx.doi.org/10.19045/bspab.2016.

50114 Published by Bolan Society for Pure and Applied Biology. Pure Appl. Biol 5(4): 906-912

3. Abro S, Kandhro MM, Laghari S, Arain MA \& Deho ZA (2009). Combining ability and heterosis for yield contributing traits in upland cotton (Gossypium hirsutum L.). Pak J Bot 41(4): 1769-1774.

4. Baloch AW, Ejaz M, Ahmad I, wasila H, Baloch MJ, Baloch GA, Yasir TA, Siddiq ur Rahman, Hayat S, Shah SNM \& Khan MA (2016). http://dx.doi.org/10.19045/bspab.2016. 50114 Published by Bolan Society for Pure and Applied Biology 906. Pure Appl Biol 5(4): 906-912.

5. Dukre VB, Potdukhe NR, Neelam Dheva \& Parmar JN (2007). Heterosis for yield, economic and morphological traits in American cotton. Annals of Plant Physiology 21(2): 236-239.

6. Zhang XG, Ni WC, Shen XL, Zhang B, Yang YW, Xu YJ \& Yao Shu (2007). Heterosis of agronomic and economic traits of cotton cultivars with high quality fiber. Jiangsu J of Agric Sci 23 (4): 276-282. 